\title{
ĐặC ĐIỂM ĐIỀU TRI VÀ KẾT QUẢ ĐIỀU TRI CỦA VIÊM PHỔI NặNG CÓ KẾT QUẢ PCR ĐÀM DƯƠNG TÍNH VỚI ADENOVIRUS Ở TRẺ TỪ 2 THÁNG ĐẾN 5 TUỔI TẠI BỆNH VIỆN NHI ĐỒNG 1
}

\author{
Trần Thanh Thức*, Trần Anh Tuấn*, Phùng Nguyễn Thế Nguyên**
}

\section{TÓM TẮT}

Muc tiêu: Mô tả đăc điểm điều trị và kết quả điều trị của viêm phổi nặng có kết quả PCR đàm dương tính với adenovirus. Đối tượng và phương pháp: Nghiên cứu mô tả hàng loạt ca, hồi cứu 55 trẻ từ 2 tháng đến 5 tuổi điều trị tại bệnh viện Nhi Đồng 1 từ tháng 4/2018 đến tháng 3/2020. Kết quả: Khoảng $1 / 3$ các trường hợp cần thở máy và gần $1 / 2$ trong số này tử vong. Các yếu tố liên quan đến nguy cơ thở máy bao gồm: tuổi nhỏ $\leq 12$ tháng, số ngày sốt kéo dài, gan to, sốc, giảm bach cầu, tăng men gan và số copies của adenovirus cao, đặc biệt là trên $72500 \times 10^{3}$ copies. $80 \%$ các trường hợp cân sử dung từ 3 loai kháng sinh trở lên và đều là các kháng sinh phổ rộng. Thời gian nằm viên trung vị là 25 ngày. Biến chứng thường gặp nhất là nhiếm trùng huyết $(45,5 \%)$. Tỉ lệ tử vong trong nghiên cứu là $16,4 \%$. Một số yếu tố liên quan như: tỉ lệ gan to, giảm bạch câu, thiếu máu, tăng AST > 100U/L, thở máy, nhiễm trùng huyết, sốc ở nhóm tử vong đều cao hơn nhóm sông, khác biệt có ý nghĩa thống kê. Kết luận: Việm phổi nặng nhiễm adenovirus ở trẻ dưới 5 tuổi có diễn tiến nặng. Mặc dù được điêuu trị tích cực với hỗ trợ hô hấp và kháng sinh phổ rộng nhưng thời gian nằm viện vân kéo dài và tỉ lệ tử vong cao.

Tư khóa: viêm phổi, adenovirus, polymerase chain reaction, trẻ em.

\section{SUMMARY}

CHARACTERISTICS AND OUTCOMES IN THE TREATMENT OF SEVERE PNEUMONIA WITH ADENOVIRUS POSITIVE SPUTUM - PCR RESULTS

\section{IN CHILDREN AGED FROM 2 MONTH TO}

\section{YEARS IN CHILDREN'S HOSPITAL 1}

Objectives: To describe the characteristics and the outcomes in treating severe pneumonia cases with adenovirus positive sputum PCR results. Subjects and methods: The retrospective study was conducted concerning a series of 55 children cases from 2 months to 5 years old at Children's Hospital 1 from April 2018 to March 2020. Results: About a third of cases require mechanical ventilation and nearly a half of them died. Factors associated with the risk of mechanical ventilation include: young age $(\leq 12$ months), prolonged fever, hepatomegaly, shock, leukopenia, elevated liver enzymes, and the high number of adenovirus copies, especially above 72500

*Bệnh viện Nhi Đồng 1

**Đai hoc Y dước Thành phố Hồ Chí Minh

Chịu trách nhiệm chính: Trần Thanh Thức

Email: thanhthuc128@gmail.com

Ngày nhận bài: 20.9.2021

Ngày phản biên khoa hoc: 8.11.2021

Ngày duyệt bài: 22.11.2021 $\mathrm{x} 10^{3}$ copies. $80 \%$ of cases require the use of three or more antibiotics which are all broad-spectrum antibiotics. Median hospital stay is 25 days. The most common complication is sepsis $(45.5 \%)$. The mortality rate in the study is $16.4 \%$. Some related factors such as the rate of hepatomegaly, leukopenia, anemia, increased AST >100U/L, mechanical ventilation, sepsis, shock... are higher in the mortality group than in the survival group, the difference is statistically significant. Conclusion: Severe adenovirus pneumonia in children under 5 years of age shows a severe progression. The hospital stay in those cases is long and the mortality rate is high, despite intensive treatments with respiratory support and broadspectrum antibiotics.

Keywords: pneumonia, adenovirus, polymerase chain reaction, children.

\section{I. ĐẶT VẤN ĐỀ}

Viêm phổi là nguyên nhân hàng đầu gây tử vong và bệnh tật ở trẻ em trên toàn thế giới, đặc biệt là các nước đang phát triển. Những dữ liệu gần đây cho thây có khoảng 120 triệu ca viêm phổi cộng đồng mỗi năm và gần 1 triệu ca tử vong ở trẻ dưới 5 tuổi, đặc biệt ở các nước thu nhập thấp [3]. Viêm phổi có thể gây ra do nhiều loại tác nhân khác nhau, tuy nhiên virus vẫn là tác nhân chiếm đa số, đặc biệt ở nhóm trẻ dưới 1 tuổi. Trong đó adenovirus là tác nhân tương đối ít gặp nhưng lại gây bệnh cảnh nặng nề và có thể để lại hậu quả lâu dài trên đường hô hấp. Việc điều trị viểm phổi do adenovirus chủ yếu là điểu trị hố trợ, chưa có thuốc kháng virus đặc hiệu, trong khi đó, việc sử dụng kháng sinh phổ rộng và phối hợp nhiêu loại kháng sinh rất thường gặp trong những trường hợp như vậy. Chưa kể đến biến chứng mạn tính trền đường hô hấp trong các trường hợp viêm phổi nặng như viêm tiểu phế quản tắc nghẽn hậu nhiếm, viêm phổi mô kẽ... gây ra một gánh nặng bệnh tật rất lớn. Vì thế, chúng tôi thực hiện nghiên cứu: "Đặc điểm điều trị và một số yếu tố liên quan đển viêm phổi nặng có kết quả PCR đàm dương tính với adenovirus ở trẻ từ 2 tháng đến 5 tuổi tại Bệnh viện Nhi Đồng 1" nhằm cung cấp dữ liệu nền tảng cho những nghiên cứu sâu hơn về tiếp cận chẩn đoán, điều trị cũng như theo dõi những trường hợp viêm phổi nặng nhiễm adenovirus.

II. ĐỐl TƯỢNG VÀ PHƯƠNG PHÁP NGHIÊN CỨU

2.1 Đối tượng nghiên cứu: Tất cả các trẻ 
từ 2 tháng đến 5 tuổi được chẩn đoán viêm phổi nặng theo tiêu chuẩn của Tổ chức $Y$ tế Thế giới và có kết quả PCR đàm dương tính với adenovirus, điều trị tại Bệnh viện Nhi Đồng 1 từ ngày 01/04/2018 đến 31/03/2020.

Tiêu chuẩn loại trừ: Các hồ sơ không đủ $X$ quang hoặc kết quả PCR đàm để xác định chẩn đoán trong quá trình hồi cứu hồ sơ hoặc mẫu đàm được đánh giá không đáng tin cậy.

2.2 Thiết kế nghiên cứu: nghiên cứu mô tả loạt ca.

2.3 Cõ mẫu và chọn mẫu: lấy trọn mẫu.

2.4 Phân tích số liệu: Số liệu thu thập được sẽ xử lí bằng phân mêm STATA Studio. Biến số định tính: tính tân số và tỷ lệ phân trăm. Biến số định lượng: tính trung bình và độ lệch chuẩn với các biến định lượng có phân phối chuẩn; giá trị trung vị, giới hạn cao nhất, thấp nhất với các biến định lượng không có phân phối chuẩn. Các phép so sánh được coi là có ý nghĩa thống kê khi có $p<0,05$.

\section{KẾT QUẢ NGHIÊN CỨU}

3.1 Đắc điểm điêu trị: Có 55 bệnh nhi thỏa tiêu chuẩn nghiên cứu với các đặc điểm:Nhiễm trùng huyết là biến chứng khá thường gặp trong các trường hợp viêm phổi nặng có kết quả PCR đàm dương tính với adenovirus (45,5\%). Thời gian nằm viện trung vị là 25 ngày, trong đó ngắn nhất là 5 ngày, dài nhất là 90 ngày. Số ngày sốt trung bình trong một đợt bệnh là 9 ngày, trong đó có 2/3 số trường hợp sốt kéo dài trên 7 ngày. Tỉ lệ tử vong trong nghiên cứu của chúng tôi là $16,4 \%$. Trong nhóm sống, có 23,9\% các trường hợp phải nhập viện lại sau đó vì khò khè kéo dài hoặc tái phát.

3.2 So sánh một số yếu tố liên quan giữa nhóm sống và nhóm tử vong:

Bảng 1. So sánh một số yêu tố liên quan giữa nhóm sống và nhóm tử vong.

\begin{tabular}{|c|c|c|c|}
\hline \multirow{2}{*}{ Đặc điểm } & \multicolumn{2}{|c|}{ Tử vong } & \multirow{2}{*}{ Giá trị P } \\
\hline & Có $(n=9)$ & Không ( $n=46)$ & \\
\hline Tuối $\leq 12$ tháng & $6(66,7)$ & $21(45,7)$ & $0,295^{b}$ \\
\hline Suy dinh dưỡng & $2(22,2)$ & $9(19,6)$ & $1,000^{\mathrm{b}}$ \\
\hline Gan to & $7(77,8)$ & $12(26,1)$ & $0,005^{b}$ \\
\hline Giảm bạch câu & $6(66,7)$ & $10(21,7)$ & $0,013^{b}$ \\
\hline Giảm Neu & $6(66,7)$ & $20(43,5)$ & $0,281^{b}$ \\
\hline Giảm Lym & $4(44,4)$ & $6(13,0)$ & $0,047^{b}$ \\
\hline Thiếu máu & $8(88,9)$ & $20(43,5)$ & $0,025^{b}$ \\
\hline AST > 100U/L & $8(88,9)$ & $16(34,8)$ & $0,007^{b}$ \\
\hline Thở máy & $9(100)$ & $11(23,9)$ & $<0,001^{b}$ \\
\hline Nhiêm trùng huyết & $9(100)$ & $16(34,8)$ & $<0,001^{b}$ \\
\hline Sốc & $7(77,8)$ & $0(0)$ & $<0,001^{b}$ \\
\hline
\end{tabular}

(b): Phép kiểm chính xác Fisher.

3.3 So sánh một số yếu tố liên quan giữa nhóm có thở máy và không thở máy:

Bảng 2. So sánh một số yêu tố lâm sàng, cận lâm sàng giữa nhóm có và không thở máy

\begin{tabular}{|c|c|c|c|}
\hline \multirow{2}{*}{ Đặc điểm } & \multicolumn{2}{|c|}{ Thở máy } & \multirow{2}{*}{ Giá trị P } \\
\cline { 2 - 4 } & Có $(\mathbf{n}=\mathbf{2 0})$ & Không $(\mathbf{n}=\mathbf{3 5})$ & $\mathbf{0 , 0 1 9}^{\mathbf{a}}$ \\
\hline$\leq 12$ tháng & $14(70,0)$ & $13(37,1)$ & $<\mathbf{0 , 0 0 1}^{\mathbf{c}}$ \\
\hline Tống số ngày sốt & $12,9 \pm 3,8$ & $6,7 \pm 4,3$ & $<\mathbf{0 , 0 1}^{\mathbf{b}}$ \\
\hline Sốt $\geq 7$ ngày & $20(100)$ & $15(42,9)$ & $1,000^{\mathrm{b}}$ \\
\hline Suy dinh dưỡng & $4(20,0)$ & $7(20,0)$ & $0,215^{\mathrm{b}}$ \\
\hline Khò khè & $17(85,0)$ & $24(68,6)$ & $<\mathbf{0 , 0 1}^{\mathbf{a}}$ \\
\hline Gan to & $13(65,0)$ & $6(17,1)$ & $<\mathbf{0 , 0 1}^{\mathbf{b}}$ \\
\hline Sốc & $7(35,0)$ & $0(0)$ & $\mathbf{0 , 0 0 1}^{\mathbf{a}}$ \\
\hline Giảm bạch câu theo tuối & $11(55,0)$ & $5(14,3)$ & $0,153^{\mathrm{a}}$ \\
\hline Giảm Neu theo tuối & $12(60,0)$ & $14(40,0)$ & $0,144^{\mathrm{b}}$ \\
\hline Giảm Lym theo tuối & $6(30,0)$ & $4(11,4)$ & $0,114^{\mathrm{a}}$ \\
\hline Thiếu máu & $13(65,0)$ & $15(42,9)$ & $0,059^{\mathrm{b}}$ \\
\hline Giảm tiếu câuu $<150 \mathrm{k} / \mathrm{mm}^{3}$ & $6(30,0)$ & $3(8,6)$ & $0,457^{\mathrm{d}}$ \\
\hline CRP & $18,1(4,2-38,7)$ & $7,8(3,4-33,2)$ & $\mathbf{0 , 0 1 6}^{\mathbf{a}}$ \\
\hline AST > 100 U/L & $13(65,0)$ & $11(31,4)$ & $0,096^{\mathrm{b}}$ \\
\hline ALT > 100 U/L & $5(25,0)$ & $3(8,6)$ & \\
\hline
\end{tabular}


(a): Phép kiểm Chi bình phương. (b): Phép kiểm chính xác Fisher. (c) Phép kiểm t không bắt cặp. (d): Phép kiểm Mann-Whitney.

Bảng 3. So sánh kêt quả PCR đàm giữa nhóm có và không thở máy.

\begin{tabular}{|c|c|c|c|}
\hline \multirow{2}{*}{ Đặc điểm } & Có $(\mathbf{n}=\mathbf{2 0})$ & \multirow{2}{*}{ Thá trị P $\mathbf{P}$} \\
\cline { 2 - 4 } & $14(70,0)$ & Không $(\mathbf{n}=\mathbf{3 5})$ & $0,267^{\mathrm{a}}$ \\
\hline Đồng nhiềm & $29(82,9)$ & $<\mathbf{0 0 1}^{\mathbf{d}}$ \\
\hline Số copies (x10
\end{tabular}

(a): Phép kiểm Chi bình phương. (d): Phép kiếm Mann-Whitney.

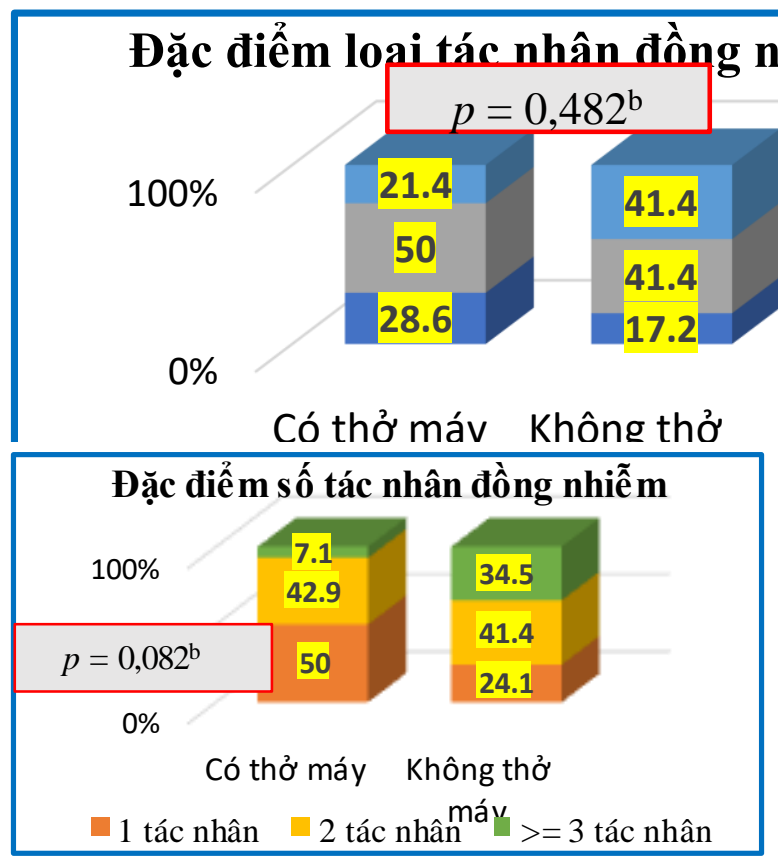

Biểu đồ 1. Đặc điểm đồng nhiễm trên kêt quả PCR đàm giữa 2 nhóm.

\section{BÀN LUÂ̂N}

4.1 Đặc điểm điêu trị: Có khoảng $2 / 3$ số trường hợp trong nghiên cứu của chúng tôi cần hỗ trợ hồ hấp với ít nhất bằng oxy canulla. Khoảng $1 / 3$ các trường hợp cần thở máy xâm lấn và gần $50 \%$ trong số này tử vong. Tỉ lệ này ở một số nghiên cứu khác cũng có một số khác biệt. Ví dụ nghiên cứu của Zampoli [6] trên nhóm trẻ viêm phổi nhiễm adenovirus nhập viện nói chung, thì có $36,9 \%$ số bệnh nhân cần nhập hồi sức để hỗ trợ hô hấp, trong số đó, $71 \%$ cần thở máy xâm lấn, 40,8\% cần thở áp lực dương liên tục và $17,1 \%$ cần thở rung tần số cao. Nghiên cứu của Li Min Lim [2] cũng trên nhóm trẻ viêm phỗi nhiễm adenovirus nói chung thì tỉ lệ cần hỗ trợ hô hấp là $67,4 \%$ và tỉ lệ thở máy là 18,5\%. Trong khi đó, nghiên cứu của tác giả Jingyi Shi [4] và Nguyễn Thị Mai Thùy [1] thì nghiên cứu trên nhóm bệnh nhân nằm hồi sức tích cực nên tỉ lệ cần thở máy xâm lấn cao hơn lần lượt là $92,5 \%$ và $77,8 \%$.
Tỉ lệ sử dụng từ 3 loại kháng sinh tĩnh mạch trở lên trong nghiên cứu của chúng tôi chiếm đến $80 \%$ các trường hợp. Lí do các trường hợp trong nghiên cứu của chúng tôi phải đổi kháng sinh nhiều lần và sử dụng nhiều loại kháng sinh là do các bệnh nhân trong nghiên cứu của chúng tôi thường nhập viện ở thời điểm ngày thứ 2-5 của bệnh và trong tình trạng không nặng (đa số là suy hô hấp độ 1) nển thường được dùng kháng sinh theo liệu pháp lên thang. Sau đó, các trường hợp này thường diễn tiến sốt kéo dài, các triệu chứng hô hấp thuyên giảm chậm, nên thường được nâng bậc kháng sinh sớm dựa theo lâm sàng mà không chờ kết quả cấy, đến cuối cùng, cặp kháng sinh phối hợp thường gặp nhất trong nghiên cứu của chúng tôi là Carbapenem và Vancomycin (xấp xỉ $75 \%$ trường hợp) và tỉ lệ sử dụng Colistin cũng rất đáng báo động (45,5\%).

4.2 Đặc điểm kết quả điều trị: Tî lệ tử vong trong nghiên cứu của chúng tôi là $16,4 \%$. Tỉ lệ này tương đương với nghiên cứu của tác giả Jingyi Shi [4] (16,4\%) nhứng thấp hơn các nghiên cứu của tác giả Nguyễn Thị Mai Thùy [1] $(33,3 \%)$ và cao hơn nghiên cứu của Zampoli [6] $(8,7 \%)$ và Li Min Lim [2] $(5,4 \%)$. Nguyên nhân tử vong thường gặp nhất là viêm phổi nặng kém đáp ứng với điều trị dẫn đến suy hô hấp nặng hoặc sốc nhiễm trùng dẫn đến tử vong. Sự khác biệt về tỉ lệ tử vong qua các nghiên cứu có thể do đối tượng trong các nghiên cứu khác nhau về tiên căn bệnh lí, độ nặng, cũng như là sự khác nhau về các biện pháp điểu trị sẵn có và phác đồ điều trị tại mỗi đơn vị.

4.3 Một số yếu tố liên quan đến tử vong trong viêm phổi nặng nhiễm adenovirus: Có nhiều yếu tố liên quan đến việc tăng nguy cơ tử vong trong viêm phổi nhiễm adenovirus đã được tìm thây qua nhiều nghiên cứu. Nghiên cứu của Zampoli [6] chỉ ra rằng giảm oxy máu, cần nhập hồi sức tích cực, bệnh lý tim nền và cấy máu dương tính là các yếu tố liên quan đến tử vong nội viện của viêm phổi liên quan adenovirus. Nghiên cứu của Nguyễn Thị Mai Thùy [1] chỉ ra các yếu tố độc lập làm tăng nguy cơ tử vong ở bệnh nhân viêm phổi nặng nhiếm adenovirus là tình trạng gan to và giảm bạch cầu theo tuổi. 
Nghiên cứu của Jingyi Shi [4] thì laai thấy rằng rối loạn chức năng gan và nhiếm khuẩn bệnh viện là các yếu tố nguy cơ độc lập của tử vong qua phân tích hồi quy logistic đa biến. Trong nghiên cứu của chúng tôi, khi so sánh giữa nhóm sống và nhóm tử vong (Bảng 1 ), chúng tôi cũng ghi nhận được một số kết quả tương đối phù hợp với các nghiên cứu kể trên như: tî lệ gan to, giảm bạch cầu theo tuổi, giảm Lym theo tuổi, thiếu máu và $A S T$ tăng trên $100 \mathrm{U} / \mathrm{L}$ ở nhóm tử vong cao hơn nhóm sống, khác biệt có ý nghĩa thống kê $(p<0,05)$; ngoài ra tỉ lệ cần hỗ trợ hô hấp bằng thở máy và tỉ lệ biến chứng nhiểm trùng huyết, sốc đều cao hớn ở nhóm tử vong khi so với nhóm sống $(p<0,05)$.

4.4 Mốt số yếu tố liên quan đến nguy cơ thở máy trong viêm phổi nặng nhiễm adenovirus: Giống như nhiều nghiên cứu khác [1], [2], [4] về các yếu tố liên quan đến tiên lượng nặng của viêm phổi nhiễm adenovirus, khi so sánh hai nhóm có và không có thở máy, chúng tôi cũng ghi nhận được tî lệ nhóm tuối $\leq 12$ tháng, tỉ lệ sốt kéo dài trển 7 ngày, tỉ lệ gan to, sốc, giảm bạch cầu theo tuổi và men gan AST $>$ 100U/L ở nhóm thở máy đều cao hơn nhóm không thở máy, khác biệt có ý nghĩa thống kê $(p<0,05)$. Kết quả $P C R$ đàm giữa hai nhóm có và không có thở máy không có khác biệt có ý nghĩa về các yếu tố nền như tỉ lệ đồng nhiễm, số tác nhân đồng nhiễm hay loại tác nhân đồng nhiễm. Chính vì sự đồng đều về kết quả PCR giữa hai nhóm như vậy, nên sự khác biệt về tải lượng adenovirus lại càng thêm có ý nghĩa. Kết quả này một lần nữa khẳng định tác động của tải lượng virus lên mức độ nặng của viêm phổi nhiễm adenovirus. Một nghiên cứu của tác giả Leyun Xie [5] cũng cho thấy rằng, tải lượng adenovirus ở nhóm viêm phổi nặng cao hơn nhóm viêm phổi nhẹ, khác biệt có ý nghĩa thống kê $(p<0,05)$, kể cả ở nhóm đơn nhiễm và nhóm có đồng nhiễm tác nhân khác (bao gồm vi-rút khác, vi khuẩn). Tác giả cũng vẽ đường cong ROC để thể hiện mối liên hệ giữa tải lượng adenovirus và mức độ nặng của viêm phổi trong 2 trường hợp: đơn nhiếm và đồng nhiễm. Kết quả cho thấy diện tích dưới đường cong của tải lượng adenovirus trong tiên đoán mức độ nặng của bệnh trong hai trường hợp đơn nhiểm và đồng nhiễm lần lượt là 0,818 và $0,782(p<0,05)$. Để nói lên mối liên hệ này một cách rõ ràng hơn, chúng tôi cũng tiến hành vẽ đường cong ROC của tải lượng adenovirus trong tiên đoán khả năng thở máy ở bệnh nhân viêm phổi nặng có kết quả PCR đàm dương tính với adenovirus trong nghiên cứu của chúng tôi (Biểu đồ 5) với diện tích dưới đường cong là 0,773 và khoảng tin cậy $95 \%$ của AUC là $0,631-0,914$. Hơn nữa, nếu chọn cut-off của tải lượng adenovirus là $72500 \times 10^{3}$ copies thì độ nhạy và độ đặc hiệu để tiên đoán khả năng thở máy trong nghiên cứu của chúng tôi lần lượt là $80 \%$ và $80 \%$.

\section{KẾT LUẬN}

Khoảng $1 / 3$ các trường hợp viêm phổi nặng nhiễm adenovirus trong nghiên cứu của chúng tôi cần thở máy và gần $1 / 2$ trong số này tử vong.

Các yếu tố liên quan đến nguy cơ thở máy bao gồm: tuổi nhỏ $\leq 12$ tháng, số ngày sốt kéo dài, gan to, sốc, giảm bạch cầu, tăng men gan và số copies của adenovirus cao, đặc biệt là trên $72500 \times 10^{3}$ copies.

$80 \%$ các trường hợp cần sử dụng từ 3 loại kháng sinh trở lên và đều là các kháng sinh phổ rộng. Thời gian nằm viện trung vị là 25 ngày.

Tỉ lệ tử vong trong nghiên cứu là 16,4\%. Một số yếu tố liên quan như: tỉ lệ gan to, giảm bạch cầu, thiếu máu, tăng AST >100U/L, thở máy, nhiếm trùng huyết, sốc ở nhóm tử vong đều cao hơn nhóm sống, khác biệt có ý nghĩa thống kê.

Tóm lại, viêm phổi nặng nhiểm adenovirus ở trẻ dưới 5 tuổi có diễn tiến nặng, dù được điều trị tích cực với hỗ trợ hô hấp và kháng sinh phổ rộng nhưng thời gian nằm viện vẫn kéo dài và tỉ lệ tử vong cao.

\section{TÀI LIỆU THAM KHẢO}

1. Nguyễn Thị Mai Thùy, Tạ Anh Tuấn, Đậu Viêtt Hừng (2018), "Đặc đ̛̣iểm dịch tễ lâm sàng cận lâm sàng của viêm phổi nặng nhiễm adenovirus tại khoa điều trị tích cức bênh viện Nhi TƯ", Tap chí Y học Việt Nam, 497(2), 170-73.

2. Li L., Woo Y. Y., de Bruyne J. A., et al. (2018), "Epidemiology, clinical presentation and respiratory sequelae of adenovirus pneumonia in children in Kuala Lumpur, Malaysia", PLoS One, 13(10), pp. e0205795.

3. Liu L., Oza S., Hogan D., et al. (2016), "Global, regional, and national causes of under- 5 mortality in 2000-15: an updated systematic analysis with implications for the Sustainable Development Goals", Lancet, 388(10063), pp. 3027-35.

4. Shi J., Zhou Y., Wang F., et al. (2020), "A case series of children with adenovirus pneumonia: three-year experiences in a tertiary PICU", BMC Pediatr, 20(1), pp. 375.

5. Xie L., Zhang B., Zhou J., et al. (2018), "Human adenovirus load in respiratory tract secretions are predictors for disease severity in children with human adenovirus pneumonia", Virol J, 15(1), pp. 123.

6. Zampoli M. and Mukuddem-Sablay Z. (2017), "Adenovirus-associated pneumonia in South African children: Presentation, clinical course and outcome", S Afr Med J, 107(2), pp. 123-26. 